\title{
The effects of intra-row spacings and cutting heights on the yield of Leucaena leucocephala in Adana, Turkey
}

TUNCAY TUKEL AND RÜSTU HATIPOGLU

\section{Abstract}

This research was conducted in Adann, Turkey, between 1985 and 1987. The study inveatigated the effects of the intra-row spacinga and cutting heights on yields of 2 cultivars of Leucaence leucocephala, $\mathbf{K 8}$ and Peru.

The trial was a split-split plot deaign in randomized blocks with 4 replications. The main plots were the cultivars, $\mathbf{K 8}$ and Peru; subplots were intra-row spacing, 25, 50, and $75 \mathrm{~cm}$; and sub-aub plots were cutting heighte, 20, 40, and $60 \mathrm{~cm}$. Row spacing was $1 \mathrm{~m}$.

Peru had higher leaf yields than K8. Inereased intra-row spacing decreased both thin and thick dried stem yields and folinge yield per ha. The effects of cutting heights varied with the years. The higheat dried foliage yield was obtained from the plots cut at $40 \mathrm{~cm}$ In the first year and $60 \mathrm{~cm}$ in the second year.

Key Words: intra-row spacing, forage yield, Leucaena leucocephala

Leucaena leucocephala is a multipurpose leguminous plant grown in the tropical and subtropical regions of the world (Brewbaker and Hutton 1979). This plant has been used as feed and forage for livestock, fuel, soil erosion control, and biological fertilization materials, quality cellulose for paper mills, and lumber.

$L$. leucocephala is naturalized between the latitudes of $30^{\circ}$ North and $30^{\circ}$ South (Skerman 1977). It has 3 distinct forms: Hawaiian, Peruvian, and Salvadorian types. These represent shrubby, shrubbytree, and tree forms of the species (Skerman 1977).

A preliminary research on the performance of $L$. leucocephala in our region was conducted and published in Turkish with an English summary (Tunç and Tükel 1986). In this paper, it was reported that about 4.3-7.15 tons ha ${ }^{-1}$ green foliage and $470-780 \mathrm{~kg} \mathrm{ha}^{-1}$ crude protein yields were obtained when planted at $1 \mathrm{~m}$ spacing and cut at $60 \mathrm{~cm}$ height. These and other observations gave us some indications that the $L$. leucocephala may be grown further up to the $37^{\circ}$ latitude than its commonly naturalized border and may also be used as a summer forage crop for the small animal-raising farms which usually experience green forage shortages during the peak of summer months in the region.

The main purpose of this current study was to further determine optimum intra-row space and cutting heights for $L$. leucocephala in Adana, Turkey.

\section{Material and Methods}

The study was conducted in the research plots of the Field Crops Department, Agricultural Faculty, Cukurova University, located at $37^{\circ} 21^{\prime} \mathrm{N}$ and $35^{\circ} 10^{\prime} \mathrm{E}$, throughout the years between 1985 and 1987.

The soils were young alluvial deposits of the river Seyhan having high lime contents, sandy-loam type textures, and classified as Class I land capability (Ozbek et al. 1974).

A typical coastal mediterranean climate prevails in the region with a total yearly precipitation of $642 \mathrm{~mm}$. Of this total, $323 \mathrm{~mm}$

\footnotetext{
Authors are associate professor, Department of Field Crops, College of Agriculture, Cukurova University, Adana, Turkey; and research assistant, Department of Field Crops, College of Agriculture, Cukurova University, Adana, Turkey.

Manuscript accepted 28 February 1989.
}

are received in December, January, and February (winter); 168 $\mathrm{mm}$ in March, April, and May (spring); $29 \mathrm{~mm}$ in June, July, and August (summer); and $122 \mathrm{~mm}$ in September, October, and November (fall), respectively.

Two $L$. leucocephala cultivars, K8 and Peru, were used. The former, originating from Mexico, is a giant Salvadorian tree type. The latter, originating from Argentina, is a heavily branching shrubby type.

Plots were arranged in a split-split plots design in randomized blocks with 4 replications. Size of the sub-sub plots were $3 \times 10=30$ $\mathrm{m}^{2}$. Main plots were cultivars; sub plots were intra-row spacings $(25 \mathrm{~cm}, 50 \mathrm{~cm}$, and $75 \mathrm{~cm}$ ) representing 3 planting densities as $40,000,20,000$ and 13,333 plants, $\mathrm{ha}^{-1}$; and sub-sub plots were cutting heights $(20 \mathrm{~cm}, 40 \mathrm{~cm}$, and $60 \mathrm{~cm})$.

Seeds of Leucaena cultivars were treated with hot water for about 3 minutes and soaked in the water overnight as described by Skerman (1977). Soil was removed from under Leucaena trees which were previously planted with appropriate inoculum on 6 July 1985 . This soil was placed into the rows in which the watersoaked seeds were hand sown, 3 seeds per planting position intra row spacing. Seedlings were thinned at the 3 leaf stage, and only 1 was left at each planting position.

During the next 2 years the plants were cut when they reached an average height of $1.5 \mathrm{~m}$ Four cuts in 1986 (at 14 May, 27 June, 4 Aug., and 10 Sept.) and 3 in 1987 (at 23 June, 10 Aug., and 23 Sept.) were employed, respectively. Different cutting frequencies were due to the climatic variation; the minimum temperature for initiating growth of Leucaena in spring $\left(15.5^{\circ} \mathrm{C}\right)$, as reported by Skerman (1977) and Brewbaker and Hutton (1979), was met in March 1985 and early May 1987.

Plant materials cut from each plot were separated into 3 components: thick stems $>5 \mathrm{~mm}$ diameter; thin edible stems $<\mathrm{mm}$ diameter; and leaves. This separation is customarily used for Leucaena (Gueverra et al. 1978).

\section{Results and Discussion}

\section{Thick Stem Yield}

There was no statistically significant difference between the 2 years in the yield of thick stems in spite of the different cutting frequencies. Neither was there any significant difference in the thick stem yield (Table 1) between the 2 cultivars.

However, increasing intra-row spacing significantly decreased the thick stem yield (Table 1). This finding was in support of the report by Gueverra and et al. (1978).

\section{Thin Stem Yield}

Mean thin stem yield did not show any significant effects for the years and the cultivars (Table 1). However, intra-row spacing and cutting heights affected the thin stem yield. Giving more intra-row spacing caused significant yiedd decreases. The highest yield (1.04 tons $\mathrm{ha}^{-1}$ ) was obtained from $25 \mathrm{~cm}$ intra-row spacing but the lowest yield ( 0.78 tons $\mathrm{ha}^{-1}$ ) was from $75 \mathrm{~cm}$ spacing. This was more likely due to the fact that the larger intra-row spaced plants were branching more but producing less overall yield than the narrower spaced plants, which were able to grow a greater number of plants 
Table 1. Dried yield of Leucuern leucocephala (tom ha ${ }^{-1}$ ).

\begin{tabular}{|c|c|c|c|c|c|c|c|c|c|}
\hline \multirow[b]{3}{*}{ Treatments } & \multirow{3}{*}{$\begin{array}{l}\text { Thick } \\
\text { stems }\end{array}$} & \multicolumn{2}{|c|}{1986} & ears & \multirow{2}{*}{\multicolumn{2}{|c|}{$\begin{array}{c}1987 \\
\text { Forage Yield } \\
\end{array}$}} & \multirow{3}{*}{$\begin{array}{l}\text { Thick } \\
\text { stems }\end{array}$} & \multirow{2}{*}{\multicolumn{2}{|c|}{${ }^{\text {Mean }}$ Forage Yield }} \\
\hline & & \multicolumn{2}{|c|}{$\begin{array}{c}\text { Forage Yield } \\
\end{array}$} & \multirow{2}{*}{$\begin{array}{l}\text { Thick } \\
\text { stems }\end{array}$} & & & & & \\
\hline & & Thin stems & Foliage & & Thin stems & foliage & & Thin stems & Foliage \\
\hline $\begin{array}{c}\text { Cultivars } \\
\text { K 8 } \\
\text { Peru }\end{array}$ & $\begin{array}{l}2.46 \\
2.32\end{array}$ & $\begin{array}{l}0.73 \\
0.93\end{array}$ & $\begin{array}{l}4.19 \\
4.57\end{array}$ & $\begin{array}{l}2.49 \\
2.43\end{array}$ & $\begin{array}{l}0.89 \\
1.02\end{array}$ & $\begin{array}{l}3.70 \\
4.26\end{array}$ & $\begin{array}{l}2.48 \\
2.38\end{array}$ & $\begin{array}{l}0.81 \\
0.98\end{array}$ & $\begin{array}{l}3.95 \mathrm{~b} \\
4.42 \mathrm{a}\end{array}$ \\
\hline \multicolumn{10}{|c|}{ Intra-Row Spacings (cm) } \\
\hline $\begin{array}{l}25 \\
50 \\
75\end{array}$ & $\begin{array}{l}2.89 \\
2.32 \\
1.97\end{array}$ & $\begin{array}{l}1.00 \\
0.79 \\
0.70\end{array}$ & $\begin{array}{l}5.20 \\
4.17 \\
3.78\end{array}$ & $\begin{array}{l}2.46 \\
2.29 \\
2.31\end{array}$ & $\begin{array}{l}1.07 \\
0.94 \\
0.87\end{array}$ & $\begin{array}{l}4.40 \\
3.80 \\
3.76\end{array}$ & $\begin{array}{l}2.84 \mathrm{a} \\
2.30 \mathrm{~b} \\
2.14 \mathrm{~b}\end{array}$ & $\begin{array}{l}1.04 \mathrm{a} \\
0.86 \mathrm{~b} \\
0.78 \mathrm{~b}\end{array}$ & $\begin{array}{l}4.80 \mathrm{a} \\
3.99 \mathrm{~b} \\
3.78 \mathrm{~b}\end{array}$ \\
\hline \multicolumn{10}{|c|}{ Cutting Heights (cm) } \\
\hline $\begin{array}{l}20 \\
40 \\
60\end{array}$ & $\begin{array}{l}2.72 \mathrm{a} \\
2.40 \mathrm{~b} \\
2.06 \mathrm{c}\end{array}$ & $\begin{array}{l}0.88 \mathrm{a} \\
0.87 \mathrm{a} \\
0.73 \mathrm{~b}\end{array}$ & $\begin{array}{l}4.26 \mathrm{~b} \\
4.59 \mathrm{a} \\
4.30 \mathrm{~b}\end{array}$ & $\begin{array}{l}1.97 \mathrm{~b} \\
2.57 \mathrm{a} \\
2.84 \mathrm{a}\end{array}$ & $\begin{array}{l}0.86 \mathrm{~b} \\
0.99 \mathrm{a} \\
1.02 \mathrm{a}\end{array}$ & $\begin{array}{l}3.19 \mathrm{c} \\
4.14 \mathrm{~b} \\
4.63 \mathrm{a}\end{array}$ & $\begin{array}{l}2.35 \\
2.48 \\
2.45\end{array}$ & $\begin{array}{l}0.87 \\
0.93 \\
0.87\end{array}$ & $\begin{array}{l}3.73 \\
4.36 \\
4.46\end{array}$ \\
\hline
\end{tabular}

'Means in each column with the same letters are not statistically different from each others at the 0.05 level of significance determined by the "LSD" test.

per square meter, producing fewer branches but more thin stem yield.

Effects of cutting heights on the thin stem yield revealed an inverse situation for the 2 consecutive years (Table 1 ).

\section{Dried Folinge Yield}

Cultivar Peru with a mean 4.42 tons ha $^{-1}$ dried foliage yield was significantly different and a higher yielding cultivar than $K 8$ with a mean yield of 3.95 tons $\mathrm{ha}^{-1}$. This difference was more likely due to the growth characteristics of the cultivars tested: the former a branching and the latter a giant tree type.

Dried foliage yield was also significantly affected by the intrarow spacings (Table 1$)$. The highest yield $\left(4.80\right.$ tons ha $\left.{ }^{-1}\right)$ was obtained from the $25-\mathrm{cm}$ spacing. This result indicates that the dried foliage yield can not be increased by increasing intra-row spacing more than $25 \mathrm{~cm}$. As mentioned initially, more densely sown $L$. leucocephala plants produced more thick and thin stem yields. Therefore, dried foliage yields were increased as the thick and thin stem yields increased. These findings support the claims of Sumberg (1985) and Tunç and Tükel (1986), who concluded that there was highly significant and close correlation between the stem weights and the dried foliage yield for the first and second cuts of Leucaena leucocephala.

The highest dried foliage yield ( 4.59 tons $^{-1}$ ) was obtained from the plants cut at $40-\mathrm{cm}$ heights in the first year. However, dried foliage yield was increased as the cutting heights increased, and the highest yield $\left(4.63\right.$ tons $\mathrm{ha}^{-1}$ ) was reached at the $60-\mathrm{cm}$ cutting height in the second year. This was an interesting trend which might be explained by the combining effects of the cutting heights and the cutting frequencies applied in 2 different years.

\section{Literature Cited}

Brewbaker, J.L., and E.M. Hutton 1979. Leucaena: Versatile tropical tree legume. p. 207-259 In: New Agricultural Crops, Edited by Gary, A. Ritchie A.A.A.S. Selected Symposia Series. Westview Press, Boulder, Colorado.

Gueverra, A.B., A.S. Whitney, and J.R. Thompen. 1978. Influence of intra-row spacing and cutting regimes on the growth and yield of Leucaena. Agron. J. 70:1033-37.

Ozbek, H., U. Ding, and S. Kapur. 1974. A complete soil survey of the camp area of Cukurova Univesity. Gukurova Univ. Col. of Agr. Pub. 73 Sci. Res. and Invest. 8 (In Turkish with English summary).

Skerman, P.J. 1977. Tropical forage legumes. FAO Plant Production and Protection Series 2.

Sumber, J.E. 1985. Note on estimating the forage yield of two tropical browse species. Trop. Agr. (Trinidad) 26 (1):15-16.

Tunc, S.T., and T. Tukel 1996. A research on the effects of different cutting times and frequencies on yield and some agricultural characteristics of Leucaena leucocephala (Lam) de Wit. J. Agr. Coll., Cukurova University. 1(1):66-79 (In Turkish with English Abstract). 